\title{
The Stranger and Others: The Life and Legacy of the Japanese Ethnologist Oka Masao
}

\author{
Brigitte Steger ${ }^{1}$
}

\begin{abstract}
Oka Masao (1898-1982) was a leading figure in the establishment of Japanese ethnology (cultural anthropology) since the 1930s and taught many of the next generation of ethnologists from Japan. He travelled to Vienna in 1929 to learn the methodology for studying the ethnogenesis of his own country, putting forward theories that questioned tenno-ideology of the time and became highly influential. During the war, he pushed for the establishment of an Ethnic Research Institute (Minken) to support the government in their ethnic policy in the occupied territories. Oka was also the founder of Japanese Studies at the University of Vienna in 1938. Despite these important-and at time controversial-roles, he is relatively unknown today. This article introduces recent scholarship on Oka's life and legacy. It raises important questions about the role of ethnologists in politically sensitive times and counter-balances the Anglo-American narrative of the history of ethnology or social and cultural anthropology of Japan.
\end{abstract}

Key words: Oka Masao; history of Japanese ethnology; war-time anthropology; Kulturkreislehre; Japanese Studies at the University of Vienna; Ethnic Research Institute (Minzoku kenkyüjo or Minken).

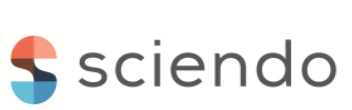

Steger, Brigitte. 2019. "The Stranger and Others: The Life and Legacy of the Japanese Ethnologist Oka Masao." Vienna Journal of East Asian Studies, 11, pp. 60-91. https://doi.org/10.2478/vjeas-2019-0003

\footnotetext{
${ }^{1}$ I would like to thank Josef Kreiner, Bernhard Scheid, Klaus Taschwer, Caspar Wits, Barak Kushner, and the anonymous reviewers for valuable comments on earlier versions of this article. I am also grateful to Mary Anketell for language editing and Kate Walker for proof reading.
} 


\section{Introduction}

Oka Masao 岡正雄 (1898-1982) is regarded as a "leading figure in the establishment of Japanese ethnology since the 1930s" (Fukui 2004: 387). As L.P. Vidyarthy (1983: 268) observed in his brief obituary, "virtually all the modern ethnologists of Japan were trained by Oka and have worked along lines he formulated." In 1943, he was instrumental in founding the Minzoku kenkyüjo 民族研究所 (Minken 民研) or Ethnic Research Institute to "conduct research in the empire on the different populations and peoples and to assist the ethnic and national policies of the Japanese civil and military administration in this realm" (van Bremen 2003: 28-29). Despite this apparent cooperation with the wartime regime, Oka played a leading role in formulating a major anthropological research project in post-war Japan aimed at critically examining the origin of the Japanese state, culture, and people in order to develop an ethnogenesis of the Japanese to replace the previous tennō 天皇 (emperor) mythology (Kreiner 2016: 24-25; van Bremen 2003: 30).

I have always been familiar with the name Oka Masao as I studied at the University of Vienna where he conducted graduate work and research from 1929-1935. In 1938, he founded and headed the Institut für Japankunde (the predecessor of the Department of Japanese Studies that merged with the Chinese Studies Department to form the Department of East Asian Studies in 2000). Yet it is only recently that Oka has received wider scholarly attention, owing in no small part to Josef Kreiner, one of his (second-generation) students and the driving force behind a recent series of research projects, conferences, and publications that attempt to assess his role and influence.

Oka's biography and work are little known in the English-speaking world; even in Japan, many younger anthropologists are unacquainted with his name. This may be due to the limited volume of his published work. Nevertheless, his important contribution to the development of ethnology as an academic discipline in Japan and of Japanese Studies in Central Europe deserves greater recognition. Even before John Embree and Ruth Benedict wrote about Japan, Oka had travelled to Vienna to learn the methodology for studying the ethnogenesis and ethnology of his own country. Thus, a study of Oka's work and his academic alliances may help to counterbalance the hegemonic Anglo-American perspective on the development of cultural anthropology in and of Japan.

Given Oka's activities in Vienna in the 1930s and prominence in Japan in the 1940s, a discussion of his life and work may also contribute to current debates on the role played by anthropologists in furthering imperialism, colonialism, and war efforts (Price 2002ab; van Bremen 2003; Gingrich and Rohrbacher forthcoming). What was the role of Oka and other representatives of Japanese anthropology in supporting the wartime Japanese government? Did anthropologists have to collaborate with the authorities? To what extent were academics able to maintain independence from 
imperialist and military goals in their work $?^{2}$ And did they make use of imperialist policies to further their own research interests and careers? Japan is an interesting case as it has been both the subject of imperialist and colonialist ambitions as well as the object of occupation. Oka's career also highlights the importance of Central European scholarship for Japan - and vice-versa - before and during the war, as well as the continuing influence of this relationship.

A full discussion of Oka's work in light of such debates is beyond the scope of a single article; moreover, a considerable amount of material remains unstudied. I hope, however, that the following presentation of Oka's life and scholarship will not only introduce this little-known scholar to an English-speaking readership but also add a new perspective to a mostly Anglo-American-centric debate on some of the questions raised above and encourage further scholarship.

\section{Early Education and Work with Yanagita Kunio}

Born in Matsumoto in Nagano Prefecture on June 5, 1898 as the youngest of eight children to a lower-ranking samurai family (his father was a judge and later a lawyer but died in 1902), Oka was educated at Matsumoto Middle School (today Fukashi High School). Having failed the entrance exam for the Third High School in Kyōto, he attended the Second High School in Sendai, the predecessor of Tohoku University. There he studied German and, due to his interest in the Russian Revolution and Marxist ideas, also taught himself Russian (Kreiner 2012: X). In 1920, Oka entered Tokyo Imperial University where he studied the new subject of sociology under Takebe Tongo 建部挀吾 (1871-1945) but was more enthusiastic about his seminars in anthropology with Torii Ryūzō 鳥居龍蔵 (1870-1953), who was one of the most prominent researchers emphasising diverse cultural influences on the origin of Japanese culture (Nakamura 2016: 215-218). Oka graduated with a thesis on the Scottish social anthropologist James Frazer's discussion of magic (Kreiner 2012: XII).

During his student days, Oka built networks with people who played an important role in his future career, including the businessman, banker, and amateur folklorist Shibusawa Keizō 渋沢敬三 (1896-1963) 3 and Okamura Chiaki 岡村千秋 (18841941), who was Yanagita Kunio's 柳田國男 (1875-1962) assistant. Thanks to Okamura's introduction, Oka began to participate in Yanagita's regular danwa-kai 談話 会, later known as the mokuyo-kai 木曜会 (Thursday meetings), and eventually became Yanagita's shosei 書生 (unpaid live-in assistant) while earning an income

\footnotetext{
${ }^{2}$ See Köck 2017 for a discussion on Martin Ramming and this question in Germany.

${ }^{3}$ Shibusawa Keizō was the grandson and heir of Shibusawa Ei'ichi 渋沢栄一, the founder of the Bank of Japan. He was two years Oka's senior at high school, but they only became closely acquainted after meeting in Yanagita's discussion circles (Oka 1981: 664-665).
} 
teaching German. Living in Yanagita's house afforded him access to a large international library and he became the note-taker for the discussion meetings (Oka 1981: 669). The presentations were published in the journal Minzoku 民族 (Ethnos), founded in 1925, which was financed by Shibusawa and published by Oka Shoin 岡 書院, the publishing house owned by Oka's older brother, Shigeo 岡茂雄. The Thursday meetings and the journal were to promote the formation of the new academic field of minzokugaku 民族学.

Minzokugaku (ethnology) is a translation of the German terms Ethnologie and Völkerkunde, as opposed to minzokugaku 民俗学 (folklore studies), which was used by Yanagita to describe his studies which focused exclusively on Japan. Minzokugaku 民族学 excluded physical anthropology, but included approaches borrowed from archaeology, history, sociology, geography, linguistics, and folklore studies (Shimizu 2003: 50). Tsuboi Shōgorō 坪井正五郎 (1863-1913), who is considered the father of Japanese anthropology, had previously used the term jinshugaku 人種学 (human species or race studies) but this had included the physical features of the people under investigation (Yamashita, Eades and Shimizu 2018: 3). The term minzokugaku had occasionally been used by Oka's teacher Torii, but Oka is credited with having popularised the term in Japan (Yamashita, Eades and Shimizu 2018: 3). It fell to him to introduce the term to readers in the journal's inaugural issue (Shimizu 2013: 71-73; article reprinted in Oka 1979: 51-60). ${ }^{4}$

Oka also joined Shibusawa's discussion group "Attic Museum" and, along with other recent graduates such as Yahata Ichirō 八幡一郎, Egami Namio 江上波夫, Furuno Kiyoto 古野清人, Suda Akiyoshi 須田昭義, and Sasaki Hikoichirō 佐々木彦 一郎, organised the so-called jinbun kenkyūkai 人文研究会 (Humanities Research Group; founded around 1927). This group was disbanded two years later but reconvened in November 1936 as the APE-kai (which stands for "anthropology, prehistory and ethnology" but also refers to the English word "ape" to express the belief that its members and their scholarship were still at an early stage of development) (Minerva 1937). It was to play an important role in the formulation of ethnology in Japan (Kreiner 2012: X-IX, XIV; Kreiner 2016: 6-9; Kreiner 2017: 23-31; Linhart 2016: 63-66).

At one of Yanagita's Thursday meetings in early 1929, Orikuchi Shinobu 折口信 夫 $(1887-1953)^{5}$ presented his research on the belief that other-worldly beings

\footnotetext{
${ }^{4}$ In the 1960s, there was a debate in Japan about changing the name of the field to bunka jinruigaku 文化人類学 (cultural anthropology). Finally, in April 2004, the Japanese Ethnological Society (Nihon Minzoku gakkai) was renamed Nihon bunka jinrui gakkai 日本文化人類学会 or The Japanese Society of Cultural Anthropology (JASCA). See: http://www.jasca.org/publication/jjca/framejjca.html.

${ }^{5}$ Orikuchi was a scholar of religion, ancient literature, linguistics, ethnology and folklore, as well as a novelist. On Orikuchi's life and work, see Nakazawa Shin'ichi's 2008 book Orikuchi Shinobu:
} 
(marebito 客人、賓 $)^{6}$ visit the community at certain times during the year. This work was based on a comparison of Okinawan culture and the Manyōsh $\bar{u}$ 万葉集, the oldest (late eighth century) existing collection of Japanese poetry. During festivals (matsuri 祭り), such other-worldly visitors are represented by singing and dancing men in masks and costumes, and Orikuchi believed this to be the origin of theatrical forms such as dengaku 田楽 and sarugaku 猿楽. Yanagita dismissed his research, criticising its methodological weakness, and refused to allow its publication in Minzoku. Oka, however, was inspired by these ideas and published his first article "Ijin sono ta" 異 人その他 (Strangers and Others) (Oka 1929, reprinted in Oka 1979), in which he built upon Orikuchi's argument. Oka compared examples of silent trade ${ }^{7}$ and trade with others from beyond one's locality in Japan with examples from Melanesia, noting the significance of the outsider/stranger for communities in both cultures. This radically questioned the view - upheld by both Yanagita and Orikuchi-that the marebito belief had uniquely emerged from Japanese rice-growing culture and suggested a common origin of Japanese and Melanesian cultures, or at least some kind of early relationship and exchange. Oka's publication gave rise to a debate about the potential plurality of origins of the Japanese culture as it questioned mainstream ideas of the cultural and racial homogeneity of the Japanese nation. Given the attention that his work had attracted, Oka felt morally obliged to acknowledge Orikuchi's previous research and published Orikuchi's original article “Tokoyo oyobi marebito" 常世及び まれびと (The Other World and Marebito; cf. Orikuchi 1929) two months later without Yanagita's permission. This resulted in a major falling-out between Yanagita and Oka (Kreiner 2012: XIII-XIV; Kreiner 2017). ${ }^{8}$

Kodai kara kita miraijin 折口信夫:古代から来た未来人 (Orikuchi Shinobu: The People of the Future Who Came from Ancient Times) and the 2014 NHK series based on it.

${ }^{6}$ Marebito are divine visitors believed to bring blessings and luck from the other world (tokoyo 常 世) (Kodansha Encyclopedia of Japan 1999).

${ }^{7}$ Also known as dumb barter, this refers to methods by which traders who do not share a common language conduct transactions without verbal communication.

${ }^{8}$ It is unclear why Yanagita opposed the publication of the article so strongly, especially as he had been responsible for sending Orikuchi to Okinawa to conduct the research. However, Yanagita was well known for his difficult temperament and at that time was also in conflict with Oka Shigeo (for details, cf. Christy 2012: 221-223). There were also rumours of personal reasons for the altercations between Yanagita and Oka Masao (Kreiner 2016: 8). His falling-out with Yanagita may have been the reason why Oka dared to openly criticise his former mentor for his dictatorial style and his poor treatment of the numerous village correspondents who provided material about their lives for his publications; these "anonymous soldiers" received neither payment nor acknowledgment while "General" Yanagita reaped the fame (Meshcheryakov 2018: 80). 


\section{Student Days in Vienna (1929-1935)}

Oka "had to flee" from Tōkyō and was so "desperate" (desupere デスペレ) that he considered becoming a primary school teacher in his home town of Matsumoto. However, Shibusawa offered him a generous scholarship to study abroad and Oka chose Vienna in order to work with Wilhelm Schmidt and Wilhelm Koppers, whose book Völker und Kulturen ${ }^{9}$ he had found on the bargain shelf in a bookshop in Tōkyō in 1924 and read assiduously (sesse to せっせと) (Oka 1981: 666-667, 669-670). The book had set out to synthesise the whole range (both in terms of methodology and of regional specialisation) of existing ethnological studies and data in order to develop a theory on ethnogenesis: the Kulturkreislehre (culture circle theory, see below). For Oka, it provided a systematic methodology that allowed him to make sense of and classify the various randomly selected ethnographic works he had read. Taking the Trans-Siberian Railway, Oka visited anthropologists and ethnologists in Leningrad and Northern Europe before arriving in Vienna in July 1929, which was then-in his view-the "Mecca of ethnology" (Oka 1981: 667, 670; Kreiner 2016: 9-10; Marschall 2016).

In Vienna, Oka interacted with a large number of scholars representing a wide variety of approaches but mostly focused his attention on the fields of ethnohistory and ethnogenesis. Eventually, he decided to work on a Ph.D. and his dissertation supervisor was Wilhelm Koppers (1886-1961), the first head of the Department of Ethnology (Völkerkunde), which had become independent from the Museum of Ethnology in May 1928. Koppers was a Catholic priest and had been trained by Wilhelm Schmidt (1868-1954), the most influential ethnologist of the "Vienna School." Schmidt, a Catholic priest and gifted linguist, was a member of the Society of the Divine Word (Societas Verbi Divini or SVD) in charge of educating missionaries at the Monastery of St. Gabriel in Mödling, south of Vienna. He acted in the role of confessor to the last emperor Karl Habsburg (until 1918 when Austria became a republic), which gave him political influence, and was also founding editor of the journal Anthropos. His explicit aim was to infiltrate academia with Catholicism and to ethnologically prove the existence of a monotheistic god. Ideologically, he was an anti-Semite and a supporter of the Austro-fascist regime after 1934, but he was opposed to National Socialism ${ }^{10}$ (Scheid 2016: 64).

\footnotetext{
${ }^{9}$ The full title is Völker und Kulturen: Gesellschaft und Wirtschaft der Völker (People and Cultures: Society and Economy of the People) (1924). It was envisioned as the first volume of a series Der Mensch aller Zeiten: Natur und Kultur der Völker der Erde (Humankind of All Times: Nature and Culture of All People on Earth), but the subsequent volumes were never completed.

${ }^{10}$ Ideologically, Austro-fascism was close to Italian fascism; it was Catholic, corporatist and espoused Austrian nationalism. It must be differentiated from National Socialism, which was panGerman nationalistic. Both shared certain ideological views, such as anti-communism, racism and anti-Semitism, but the anti-Semitism of the Austro-fascists was based on religious and ethnic
} 
Schmidt's oeuvre is extensive, and his ideas changed over the fifty years of his active life. ${ }^{11} \mathrm{He}$ summarised some of his theories in a lecture presented in Japan and translated by Oka; this was published in bilingual form in Schmidt 1935a, discussed in Scheid forthcoming. In the same year, Schmidt (1935b) also published a lecture on "the oldest culture circles in Asia" in the inaugural issue of Monumenta Serica, the journal of the Catholic Fu Jen University 輔仁大學 in Beijing, owned by SVD which he presented in English.

Schmidt developed a culture-historical method and applied it in his work to reconstruct the oldest common religion of humankind (Zimoń 1986: 245-246). His ethnology, which he had also applied in Völker and Kulturen (the book that had fascinated Oka) focused on two main concepts: the diffusion of culture in circles based on social structure and economic relations, the so-called Kulturkreislehre (culture circle theory); and the theory of primordial monotheism. He understood culture as "the intelligent and purposeful shaping of matter by the mind, the forming of social relations, the expression of thoughts in words and the deportment of the body, each of these being an outward expression of the inward soul." He stated that "no culture-less people can be found in the whole world" and that the term "nature-people" was an oxymoron that should never be used (Schmidt 1935b: 2).

Schmidt promoted the idea of a primordial culture circle (Urkulturkreis) $)^{12}$ located in Asia and represented by monogamous hunter-gatherer societies which had "a division of labour according to sex" (the "husband supplies the meat for the table by hunting; the wife, the vegetables by gathering plant products"). Importantly, they believed in a single supreme god (Hochgott) (Schmidt 1935b: 4). In Schmidt's view, such monotheism did not exclude belief in the existence of other higher beings, as long as they were created and controlled by the Hochgott and their existence did not prevent a direct relationship between people and this Supreme Being (Zimoń 1986: 247).

(völkisch) ideas, whereas the anti-Semitism of the National Socialists was based on biological racism (Taschwer 2017). Overt anti-Semitism was not government policy during the period of Austro-fascism (1934-1938) and many Jews from Germany moved to Austria before the Anschluss in March 1938. The Nazi Party (NSDAP) was banned in Austria between June 1933 and March 1938, but after the Anschluss the Nazis expelled Catholic missionaries in order to make use of ethnology/ Völkerkunde for their own purposes (Andre Gingrich in Der Standard, April 28, 2009; Gingrich and Rohrbacher forthcoming).

${ }^{11}$ Schmidt's theories were studied widely but, to the best of my knowledge, the only comprehensive study of his large corpus of publications was carried out in Polish by Henryk Zimon, a professor of history of religion and ethnology at the Catholic University of Lublin and member of the Anthropos Institute, in a postdoctoral thesis (habilitation). He summarised his major findings in English in the journal Anthropos (Zimoń 1986).

${ }^{12}$ Schmidt (1935b: 3) translates Urkultur as "primitive culture" and explains that it is the same as Menghin's term "old cultures" (Altkulturen) and what Fritz Kern calls "hunting cultures" (Wildbeuterkulturen). Zimoń (1986) uses the term "primeval culture" to translate Urkultur, but "primordial culture" is closest to its meaning and connotations. 
Schmidt believed that a revelation by the supreme god was a shared characteristic of early cultures and thus concluded that the primordial culture must have been monotheistic (Marschall 2016: 89). As the historicity of this revelation is based on theological premise rather than ethnological investigation (Zimon 1986: 250), Schmidt's theories of a primordial monotheistic culture are a question of faith rather than scientific evidence.

According to Schmidt's culture circle theory, when the primordial culture was pushed to the extreme north and south through migration, three primary culture circles emerged and developed: one was characterised by patriarchal totemistic hunters; the second by matriarchal agriculturalists; and the third by patriarchal pastoral cattlebreeders. Secondary and tertiary culture circles developed from there through migration and the mixing of cultures (Schmidt 1935b; Linhart 2016: 72). Several circles could exist contemporaneously in a specific region and, when ordered in a relative chronology with respect to their first appearance, they formed so-called Kulturschichten (cultural strata) (Kluckhohn 1936: 134). By comparing cultural similarities between people living in different regions, Schmidt and his followers attempted to identify culture circles according to criteria such as material culture, social organisation and economic structure in an attempt to include the whole of humankind throughout history (Zimoń 1986: 245).

Schmidt argued that the Urkulturkreis with its monotheistic supreme god had outlived all other culture circles and had become established in the Christian culture of the day; this supported his belief in the superiority of Christian culture and the quasidegenerate nature of polytheistic culture circles (Linhart 2016: 72). Thus, Schmidt and Koppers argued strongly against the evolutionists and their theory that the direction of human development was from the simple and primitive towards the complex and civilised (Marschall 2016: 87). This may have been because evolutionism, Darwinism, and socialism were hostile towards religion and the Church (Scheid 2016: 67); however, as Zimoń (1986: 245) points out, Schmidt was not totally free from the influence of evolutionary theory.

Schmidt did not conduct field research himself but sent his students, fellow priests and monks out into the world to confirm his theories which he promoted dogmatically (Scheid 2016: 65). In an interview (danwa 談話) published in a kind of Festschrift for Shibusawa Keizō, however, Oka emphasises that Schmidt never tried to convert him to Catholicism (1981: 670).

Another of Oka's influential teachers was the Southeast Asian specialist Robert Heine-Geldern (1885-1968). He was of Jewish ancestry and had studied philosophy, art history, prehistory and classics in both Munich and Vienna. As a wealthy aristocrat (his father had been knighted), he had the independent means to travel and conduct extensive field research, particularly in eastern India and Burma, and submitted his Ph.D. thesis on mountain tribes in Burma in 1914 (Marschall 2016: 86). Like Schmidt and Koppers, Heine-Geldern was interested in ethnohistory and "diffusionism" (rather 
than evolutionary theory), but he fiercely opposed Schmidt's methodology and ideas of primordial monotheism and race. As early as 1921, he set about discrediting Schmidt's theories on the Austroasiatic race (i.e. equating the Austroasiatic language family with a common race), revealing a lack of data and extensive manipulation of evidence to fit the theory (Scheid 2016: 71; Marschall 2016: 87). With an astute intellect and financial and institutional independence (from 1918 to 1928 he worked at the Museum of Ethnology, originally as a volunteer), Heine-Geldern not only countered the Kulturkreislehre but also made important contributions of his own. He was the first to propose the notion of "Southeast Asia" as a cultural-historical entity and elaborated upon its historical cultural configuration (Kulturaufbau) in great detail. He stressed that there was nothing like the culture of Southeast Asia; instead the way of life of each group and society within it contains elements from many sources. HeineGeldern's research was acknowledged worldwide but mostly ignored closer to home by the Vienna School, where his Jewish heritage and his critical attitude towards Schmidt hampered his career.

In 1925, Heine-Geldern earned his habilitation (the qualification required to become a professor) at the University of Vienna (Marschall 2016: 94-95). This was remarkable as at that time many Jewish academics were denied this privilege on the pretext that their personality or their qualifications were not suitable for becoming a professor. On occasion, even decisions by an academic committee were overturned, especially in the Faculty of Philosophy to which the study of ethnology belonged (cf. Taschwer 2015a: 99-132). ${ }^{13}$ Despite his habilitation and international reputation, however, Heine-Geldern was not granted a proper position and was paid very little when he became Honorary Professor between 1931 and 1938. By this time, he was in dire financial straits as his family wealth had been decimated by the world economic crisis and a bad investment in World War I loans. In January 1938, shortly before the Anschluss, he accepted an invitation to give lectures in the United States and moved to New York with his family, where he stayed until 1949 (Marschall 2016: 96, 100).

The prehistorian Oswald Menghin (1888-1973) was also an important influence on Oka, who in 1942-43 translated Menghin's book Weltgeschichte der Steinzeit (World History of the Stone Age, 1931, $2^{\text {nd }}$ ed. 1940) in order to use it as a model for writing world history from the perspective of Japan in Asia (Oka 1979: 243-261). Menghin was interested in race and the origin of world culture and was at home in both conservative Catholic and national socialist circles (see footnote 10). He was a member of the Deutscher Klub, an openly anti-Semitic organisation of Viennese bourgeois German nationalists and national socialists, and was also a member of the socalled Bärenhöhle (Bear Cave), a secret circle of eighteen professors who exerted

\footnotetext{
${ }^{13}$ At that time, the Faculty of Philosophy included the humanities, the natural sciences and indeed most disciplines, while the other faculties were those of theology, law and state theory (which included economy and sociology), and medicine.
} 
great influence within the Faculty of Philosophy, especially the humanities (Taschwer 2015a: 109-113; Erker, Huber and Taschwer 2017).

Menghin acted as faculty dean (1928-29) and rector of the University of Vienna (1935-36) and, during the period between the Anschluss on March 12, 1938 and the dissolution of the Austrian government on May 31, 1938, he briefly served as Minister of Education. During this time, he decreed the so-called "cleansing" of the universities, in which approximately forty per cent of the academics at the University of Vienna were dismissed, either on account of their Jewish heritage or on political grounds. This meant that Heine-Geldern could not return from New York and Schmidt and Koppers had to leave the country and emigrate to Switzerland, even though their racist and anti-Semitic scholarship had greatly influenced national socialist anti-Semitic ideologies. After the war, Menghin escaped from an American internment camp and fled prosecution as a war criminal to Argentina (cf. Kreiner 2013; Scheid forthcoming).

Among Oka's fellow students at the time of his arrival in Vienna was Walter Hirschberg (1904-1996), an Africa specialist who helped Oka adjust to university life, taught him German and introduced him to discussion circles critical of the Kulturkreislehre (Kreiner 2013). Another fellow student, Alexander Slawik (1900-1997), was a Japan enthusiast who had taught himself some Japanese during high school and studied Chinese history at the University after abandoning his legal studies. Slawik took every opportunity to talk to the few people at the University from East Asia and befriended Oka and other Japanese, Korean, and Chinese students. Oka "seduced [Slawik] to ethnology" and they soon became close friends and collaborators (Kreiner 2013). Kreiner relates how Oka would contact Slawik by telegram whenever he needed him, often in the middle of the night, saying "Koi, Oka" (Come! Oka). Slawik would then find him lying on his sofa "as if in a trance," dictating his dissertation, which Slawik would type and presumably language edit (Kreiner 2012: XXIII). Slawik's infatuation with his friend and colleague who was two years his senior can be sensed in his description of how he "had the honour of translating the Japanese material" for one of Oka's articles (Slawik 1936: 677; quoted in Scheid 2016: 62). Both Hirschberg and Slawik were "illegal national socialists" before 1938 (Scheid forthcoming).

At this time, the Department of Ethnology was quite international and about a third of the students were foreigners (cf. Kreiner 2012: XVII for a list of international students studying with Oka). Clyde Kluckhohn (1905-1960), an American who stayed in Vienna from 1930 to 1932 and underwent psychoanalytical training with Sigmund Freud, attended lectures with Oka (Kreiner 2016: 16; Nakao 2016) and seems to have played a part in his future career. There were also two Korean students in Vienna, To Yu-ho 都宥浩 (aka Do Cyong-Ho, 1905-?) and Han Hŭng-su 韓興洙 (1909-?), ${ }^{14}$ who were classified as Japanese nationals and spoke fluent Japanese. Their social

${ }^{14}$ Both moved to North Korea after the Korean War and disappeared without trace. 
position, however, was much inferior to that of Oka; they did not receive the same support from Japanese diplomatic circles and did not benefit from Oka's social networks of politically and financially influential people. Their main source of income came from writing critical essays about Vienna for Korean newspapers. To Yu-ho had moved from Frankfurt to Vienna in 1933 to undertake a Ph.D. in Korean history under the supervision of Menghin, which he submitted in 1935. He was in regular contact with both the Department of Ethnology and Oka via their mutual friend, Slawik. Their relationship continued beyond their time in Vienna (Schirmer 2016: 169-171) and To came to Japan in 1942 to help Oka with the translation of Menghin's Weltgeschichte der Steinzeit. In the foreword to the translation, Oka acknowledges To's contribution by saying that he "would probably not have managed to publish the translation without the support of " "To-kun' [who had] studied in Vienna under the close supervision of Menghin" (Oka 1979: 249). The omission of To Yu-ho's full name, along with the use of the informal suffix "kun," suggests familiarity and implies that the Korean scholar was considered a member of the academe and Oka's readership would understand to whom he was referring. At the same time, Oka relegates To to the inferior position of a research assistant who was not acknowledged as an official translator or editor.

Kreiner writes that there were no socialists or communists in Oka's academic and social circles (Kreiner 2016: 14). Was this a conscious decision or coincidence? It is certainly true that by the early 1930s there were few left-leaning academics active at the University. During the 1920s, it was extremely difficult for a liberal or a socialist to become a professor at the University of Vienna, especially in the Faculty of Philosophy (Linhart 2016: 70; cf. Taschwer 2015a for details), and from 1934 onwards all Marxist literature was banned. There were, however, some socialists in the Department of Psychology in the early 1930s (cf. Taschwer 2015a: 186). During the period of Oka's doctoral research, Paul Lazarsfeld, Marie Jahoda, and Hans Zeisel published their famous study Die Arbeitslosen von Marienthal (The Unemployed of Marienthal; 1932), a qualitative sociological study on the impact of mass unemployment on a small community, which became internationally influential. Despite his own background in sociology and earlier interest in Marxism, I have not come across any evidence of contact between Oka and these academics nor with those working in private research institutions and community colleges where Jewish and socialist academics found alternative careers. In Uin tsūshin ウィーン通信 (Vienna Correspondence; originally 1930), Oka describes the many different departments in Vienna that offered interesting lectures; these included the Departments of Geography, History and Linguistics, but he makes no mention of the Department of Psychology or lectures in sociology (Oka 1979: 288-294). It would seem that Oka chose not to seek out progressive and politically critical members of the academic community, with the exception of Heine-Geldern. 
Oka submitted his doctoral dissertation-Kulturschichten in Alt-Japan (Cultural Strata in Ancient Japan) - in 1933;15 it consisted of three chapters plus an additional chapter of pictures and picture descriptions. His thesis passed on June 8 and Oka was awarded a Ph.D. on July 25 (Kreiner 2012: IX). At this time, there were frequent acts of terrorism and riots at the University, and on June 19 the Christian Social chancellor, Engelbert Dollfuss, dissolved parliament and banned the Nazi Party (cf. Taschwer 2015a: 133-175). I have been unable to find any mention of these events in the descriptions of Oka's life or in his own writings.

After Oka's graduation, Shibusawa suspended his financial support in an effort to persuade him to return to Japan, but Oka remained in Vienna to continue work on his manuscript financed by a scholarship from the Rockefeller Foundation (Oka 1981: 668; Scheid 2016: 72; Kreiner 2012: IX) and by teaching Japanese at the Diplomatic Academy (Konsularakademie) (Kreiner 2013). He succeeded in adding two more chapters to his opus magnum, making a total of 1,453 pages, but the work remained somewhat truncated and was only published in 2012 by Kreiner, who undertook the painstaking work of reconstructing the missing bibliography (Oka 2012; Kreiner 2012: v-vi).

In his dissertation, Oka used ethnohistorical methods to reconstruct Japanese ethnohistory, presenting a wide range of interdisciplinary material on Japanese prehistory, archaeology, anthropology, folklore studies, and material culture to emphasise the ethnic heterogeneity of Japanese culture. This transdisciplinary research methodology followed the example of his teachers but was also due to the fact that ethnology as a discipline was still at an early stage of development. In the introduction to his thesis, Oka explicitly stated his desire to contribute something new to the cultural history of Japan, which had previously been dominated by theories of race, by developing an ethnohistory and ethnology of Japan (Oka 2012: 4). Oka's arguments are mostly implied rather than clearly spelled out and his work lacks a conclusion other than a table of the various ethnic and cultural layers he had formulated and a tentative discussion of some details. The dissertation features a long chapter (over 500 pages in the 2012 version) on religion and myths but includes nothing that would support a theory of primordial monotheism nor any discussion of the question as such. Nevertheless, he clearly follows his mentor Schmidt in his ideas of cultural circles and cultural layers. Bernhard Scheid (2016: 65) argues that Schmidt's universal cultural model allowed Oka to include both diffusionist and evolutionist ideas which were believed at the time to stand in opposition to each other.

To a certain extent, Oka's lack of clear arguments may simply be a sign of poor workmanship, but many of his international contemporaries worked in a similar way. We must recognise that he was following a tradition according to which data should

\footnotetext{
${ }^{15}$ Slawik's dissertation, which he submitted in 1936, was titled Kulturschichten in Alt-Korea (Cultural Strata in Ancient Korea).
} 
be presented carefully and left to speak for themselves as arguments that are more explicit could be viewed as undermining the intellect of the reader. Kreiner recounts that in his seminars, Oka forbade his students to take notes and told them to "think for themselves" (Kreiner 2012: XXXI). To this day, there is a difference between Austrian/German and Japanese academic writing on the one hand and Anglo-American writing on the other. Even if scholars of the former tradition write in English, their articles often appear little more than a collage of detailed facts that provide the reader with few pointers on how they should be navigated. To such scholars, however, Anglo-American writing can appear opinionated and lacking in clear evidence for its arguments.

We should also be aware that vague conclusions such as in Oka's work might be a means by which academics can navigate politically sensitive times and that amassing data rather than formulating theories makes research less vulnerable to interpretation and manipulation by others in various ideological ways. Moreover, as anthropologist Jan van Bremen (2003: 29) points out, uncovering data and conducting ethnographic research has a lasting value, even when political trends and academic interests change.

While it is true that Oka followed the methodology of his teachers in Austria with little critical awareness, his idea of a multi-layered complex origin of Japanese culture contradicted the then prevailing ideology in Japan concerning the tenno (emperor) and origin of the Japanese state. Such an idea would have been strictly proscribed in Japan and may explain why Oka did not attempt to translate and publish his doctoral thesis as a book or even speak publicly about it until after the war (cf. Chun 2016).

\section{Oka's Return to Tōkyō (1935-1938)}

As noted previously, Shibusawa tried to persuade Oka to return to Japan after his graduation to lend his support to efforts to institutionalise the study of ethnology in Japan. With Shibusawa's backing, Furuno Kiyoto 古野清人, Takahashi Buntarō 高 橋文太郎 and others had founded the Nihon minzoku gakkai 日本民族学会 (Ethnological Society of Japan) in 1934 with the China specialist Shiratori Kurakichi 白鳥 庫吉 as its president. In early 1935, they launched their journal Minzokugaku kenky $\bar{u}$ 民族学研究 (Kreiner 2013; Scheid forthcoming), the same year as John Embree and his wife Ella embarked on research on a village in Kumamoto Prefecture known as Suye mura (cf. Embree 1939; Smith and Lury Wiswell 1981). ${ }^{16}$ At this time, the society had about 300 members (Shimizu 2003: 50).

\footnotetext{
16 Yanagita Kunio (Yanagida 1944: 53) wrongly dates the foundation of the association as 1935. See also: "History of Japanese Cultural Anthropology" by Ikeda Mitsuho, http://www.cscd.osakau.ac.jp/user/rosaldo/040115janth.html.
} 
Although Oka chose to stay in Vienna, he agreed to represent the Anthropological and Folklore Societies of Japan at the First International Congress of Anthropological and Ethnological Sciences in London from July 30 to August 4, 1934, where he delivered a short paper in German on "The Secret Societies in Japan, their Peculiarities and Cultural-Historical Denotations” (Hohenwart-Gerlachstein 1983: 13).

Oka finally returned to Japan on April 10, 1935. On Shibusawa's urging, he visited Yanagita, reconciled with him and gave a lecture at his former mentor's sixtieth birthday celebrations (Oka 1981: 676; Shimizu 2003: 84). The main reason for Oka's return, however, was a worldwide lecture, study, and fundraising trip by his mentor Schmidt (Oka 1981: 671; Scheid 2016: 72), whose primary objective was to visit the Catholic Fu Jen University in Beijing which had been taken over by the Society of the Divine Word. In China, Schmidt advocated that evangelistic efforts should no longer focus on the peasants in the countryside but be directed towards the intellectual urban elites so that the Catholic Church could increase its influence on Chinese culture and politics in a period of political renewal and Mao Zedong's 毛泽东 ascent to power (Rivinius 2013: 217-221). As mentioned, he also gave a lecture on "The Oldest Culture-Circles in Asia," obviously to motivate his audience to follow his academic lead (Schmidt 1935b).

Schmidt's time in Japan — a total of about two months over three visits ${ }^{17}$ —also focused on the political and economic elites. With Oka as his guide and translator and with Shibusawa's financial support and introductions, he pursued three main aims: fundraising for a Department of Japanese Studies at the University of Vienna to be chaired by Oka; promoting the institutionalisation of ethnology (in the tradition of the Kulturkreislehre) in Japan; and obtaining Shintō artefacts for the Vatican Museums. He was successful on all three counts (Scheid fortcoming). Oka (1981: 673) recalls that during his 1935 visit, Schmidt lectured the priests and monks in Japan on the need for ethnological research in Latin. However, it was not until the late 1940s that the Monumenta Serica, a branch of the Anthropos Institute at Fu Jen University and its journal of the same name, moved first to Tōkyō (1949-1955) and later to Nanzan University 南山大学 (1957-1962). ${ }^{18}$ When the institute was established in Japan, Oka and Shibusawa were asked to select the staff.

\footnotetext{
${ }^{17}$ Schmidt arrived in Japan from America on May 3 and moved on to China after two weeks. In June, Oka collected him from Beijing and they traveled together to Japan via Mongolia and Korea, where Schmidt stayed for the summer before returning to China, financed by Shibusawa. On his way back to Rome in late October, he passed once again through Japan (Scheid forthcoming: fn12). At this time, Korea and parts of China were under Japanese control.

18 See: http://www.monumenta-serica.de/monumenta-serica/institute/history/index.php. Nanzan University was founded in 1946 as the Nanzan College of Foreign Languages and was also run by SVD. It had previously (from 1932) been a high school. http://www.nanzan-u.ac.jp/English/about/ catholic/index.html
} 
Most importantly during their visit to Japan, Schmidt and Oka found a major sponsor in Baron Mitsui Takaharu 三井高陽 (1900-1983) of the Mitsui zaibatsu 三井財 閥. Mitsui had studied in Germany for four years and was interested in establishing friendship organisations between Japan and many Central European countries (Kondō 1998; Kreiner 2013, 2017; Scheid forthcoming).

\section{The Institut für Japankunde at the University of Vienna}

With Mitsui's financial help, Oka was able to put together substantial Japanese libraries destined for Berlin, Rome, and Vienna. When he returned to Vienna in February 1938, the Anschluss on March 12 and Menghin's subsequent "cleansing" policy, which completely changed the situation at the University, complicated the issue of setting up a department. Initially only a Lektor (instructor), Oka was appointed guest professor in Japanese Language and Cultural History in February 1939. ${ }^{19} \mathrm{He}$ did not undergo a selection process and his wage was determined and paid by Mitsui, while his friend Slawik - whose appointment at the Fu Jen University in 1937 had been prevented by the outbreak of war in East Asia-became a Lektor in Japanese Language. A couple of students took classes on Japan, one of whom was Thusnelda Joch (later known as Thusnelda Wang and then Nelly Naumann; 1922-2000), who earned her Ph.D. in 1946 under Koppers and was influenced by Oka's approach; she subsequently pursued an academic career in Germany (for details see Oka 1981: 677; Kreiner 2013; 2016: 20-21; 2017; Scheid forthcoming).

Oka was also the Secretary of the Japanese Austrian Friendship Society that was sponsored by Mitsui (Oka 1981: 677; Scheid forthcoming). He gave guest lectures at the universities of Budapest and Szeged in Hungary and was an active member of the Japanese Hungarian Friendship Society (Umemura 2017: 126; Kondō 1989), ${ }^{20}$ thereby supporting Mitsui's endeavours to institutionalise academic and political relationships between Japan and many European countries. Mitsui also helped finance research into Turanism which strove to demonstrate a common Turkish cultural influence across Asia (Kondō 1989: 58-59). After the Tripartite Pact was signed on September 27, 1940, he made a donation for a new building for the Japanese German Cultural Institute in Tōkyō, for which he was honoured personally by Adolf Hitler (Scheid forthcoming).

\footnotetext{
${ }^{19}$ In an interview, Oka (1981: 677) gave the impression that he had travelled to Vienna in 1938 after being appointed as guest professor (Shōwa 13nen ni Uìn daigaku no kyakuin kyōju de yobarete iku wake desu yo 昭和十三年にウィーン大学の客員教授で呼ばれて行くわけですよ).

${ }^{20}$ Oka (1981: 678) claimed that he was guest professor at the University of Budapest, commuting every other Friday-Sunday to Budapest, but his status as guest professor cannot be confirmed from the Hungarian sources, which only mention occasional lectures; for background on Japanese-Hungarian relations, see Kovácz 1987; Umemura 2017.
} 
Continuing with habits acquired during his first stay in Vienna, Oka undertook several research trips throughout Europe and as far as Turkey. The Balkans evoked his particular interest (Kreiner 2013: fn18) due to the fact that they contained many small ethnicities (shōsū minzoku 少数民族) with diverse structures, cultures, and languages. He observed that ethnic conflicts in the Balkans were often the spark (hidane 火種) for European wars and that the Ethnological Research Institute in Hungary was directly affiliated with the Ministry of Home Affairs. This was a turning point in his views on ethnological research and made him realise that ethnology should be concerned with living people, not just with history (Oka 1981: 678-679). Oka actively met with many researchers and activists to discuss the ethnic and political situation in Eastern Europe and the Near East, including Bulgarian nationalists studying their Asian roots and Hubay Kálmán (1902-1946), the interim leader of the then illegal Hungarian national socialists (Scheid forthcoming).

After Germany's invasion of Poland in September 1939, the situation both in Europe and at the University became increasingly difficult. In November 1940, Oka requested leave to spend a sabbatical in Japan to attend the memorial service for his mother who had died a year earlier (Oka 1981: 677). He did not return to Europe until 1951. His place at the University of Vienna was taken by Murata Toyofumi 村田豊 文 from the SOS Berlin (Seminar für Orientalische Sprachen, the model for SOAS at the University of London), who had no academic ambitions and made no contribution to the field of Japanese Studies or ethnology. Slawik - a member of the NSDAP even when the party was still illegal in Austria - was soon drafted into the Wehrmacht, where he worked mainly as a cryptologist and translator (Kreiner 2016: 21-22). The department was subsequently dissolved. ${ }^{21}$

\section{Wartime Anthropology in Japan}

As mentioned previously, Oka's discussion group in Japan was reactivated under the name APE-kai in 1936, at which time it had eleven members (Minerva 1937). The Ethnological Society succeeded in establishing an ethnographic museum in Hōya, Tōkyō in 1939 (Kreiner 2017) and lobbied for the establishment of ethnology as a recognised academic discipline (Kreiner 2016: 22). In a 1941 article on recent

\footnotetext{
${ }^{21}$ Diplomatic correspondence recently analysed by Scheid (forthcoming) suggests that in 1941, Oka had been considered as a candidate for the Japanese head of the Japan Institute in Berlin, indicating a closer relationship with politics than had previously been assumed. Whatever the exact situation may have been, Oka did not stay in Berlin and his involvement with politics was realised in Japan rather than Germany. The recruitment of Japan specialists as part of the war effort was not limited to Austria and Germany; the majority of their British colleagues had been involved in translating and decrypting during the war and most American anthropologists worked for the Office of War Information.
} 
developments within ethnology in Europe in the journal Kaizo 改造 (Oka 1941; Shimizu 2003: 84), Oka argued that the old-style ethnology with its focus on "primitive" people without written traditions should be reformed into present-day ethnic research investigating all groups of people (minzoku), including those of advanced culture, by means of their local languages. This can be read as a criticism of Schmidt who did not include ethnicities with written traditions in his work (cf. Zimon 1986: 246; Schmidt 1935b). According to anthropologist Nakao Katsumi, "in Vienna, Oka witnessed Nazi Germany's annexation of Austria in 1939 (sic!). He illustrated his arguments about the necessity for an Institute of Ethnology by pointing to the Nazi party's commitment to the study of folklore in establishing both the 'traditions' of the 'Aryan race' and the basis for German patriotism" (Nakao 2005: 29). As anthropologist Shimizu Akitoshi (2018: 3) points out, Oka's "idea was modelled on the Nazi's scientific policy, which promoted a new 'ethnic research' on the basis of the 'trinity' of ethnology, political science and linguistics." The group also planned to establish an Ethnic Research Institute (Minzoku kenkyüjo or Minken), and the excitement about this project postponed and ultimately rescinded Oka's plans to return to Vienna. Oka ended up playing a leading role in formulating the goals of this institute and in fundraising for it (Oka 1981: 677).

On the rail journey back to Japan from Austria in late 1940, Oka made the acquaintance of Sajima Yoshinari 佐島敬愛 (1904-1990), who had studied at the University of Wisconsin and was the director of the research division of Shōwa Tsūshō 昭和通商 (Shōwa Trading), a company that had been founded in 1939 to trade military equipment on behalf of the Japanese army. Behind the scenes, it was also involved in espionage and the illegal trading of narcotic substances. On the train, the two men started to discuss politics. Oka appears to have convinced Sajima of the importance of ethnology for the successful governance of multi-ethnic territories and, during their stopover in Moscow, Sajima asked Oka to join him on his visit to the military office (bukanshitsu 武官室) ${ }^{22}$ before boarding the Trans-Siberian Railway (Oka 1981: 680, 682-683).

Encouraged by Sajima's positive reaction, Oka visited various ministries in Tōkyō to campaign and fundraise for the establishment of a research institute to study people

\footnotetext{
${ }^{22}$ Presumably this refers to the office of the military representative at the Japanese Embassy in Moscow. Oka (1981: 680-682) writes in detail about his discussions with Sajima and about Shōwa Trading's financial support. For Sajima's position at Shōwa Trading and its secret role in intelligence gathering, I consulted http://www6.plala.or.jp/guti/cemetery/PERSON/S/sajima_yo.html, which summarises the privately published Kōno Isao. 1983. Roman o otte hachijūnen: Sajima Yoshinari no jinsei 河野勲. 1983. ロマンを追つて八十年 : 佐島敬愛の人生 (Eighty Years in Search of Adventure: The Life of Sajima Yoshinari). According to Haruna Mikio (2000: 193-196), from 1948 onwards, Sajima, who was then director of Shin-Etsu Chemicals, was a member of the "Tuesday meetings", a group of influential Japanese nicknamed the "eight samurai" who dined at The Imperial Hotel with the head of the Japan branch of the CIA, Paul Blum, every second Tuesday of the month.
} 
under Japanese imperial rule. Although the government supported the idea, it lacked financial resources. Instead, Tōa Tabako 東亜タバコ (East Asia Tobacco Company), a statutory trading company based in Manchuria, provided the funds to establish an Ethnology Foundation (zaidan hōjin Nihon Minzokugaku-kyōkai 財団法人日本民族 学協会). Sajima was appointed as the managing director (jommu riji 常務理事) of this foundation, and through his connections, Shōwa Trading financed the establishment of the Ethnic Research Institute (Minken) (Oka 1981: 680, 683).

The Minken was founded in January 1943 under the auspices of the Ministry of Education (Kreiner 2016: 22) and Oka was appointed as the head of its Administrative and Second Departments (Shimizu 2003: 85, 67). Due to Shōwa Trading's close links with the military, Minken's interdisciplinary research, including history, sociology, archaeology, linguistics, folklore studies and ethnology, was financed indirectly by the Japanese army “in order to contribute to minzoku seisaku” 民族政策 (ethnic policy) (Shimizu 2003: 66, 83-85).

In a lecture held on October 8, 1942 at an academic meeting of the Ethnological Society (Minzokugaku kenkyūkai 民俗学研究会) and published in the inaugural issue of the journal Minzokugaku kenkyu 民俗学研究 under the title "Gendai minzokugaku no shomondai” 現代民族の諸問題 (Questions/Problems of Contemporary Ethnology) (Oka 1943; reprinted in Oka 1979: 104-107), Oka proposed a new kind of Japanese ethnology. He argued that the methodologies of the three main schools of ethnology - evolutionism, cultural history (diffusionism, culture circle theory) and functionalism - were inadequate even when taken together for fully comprehending ethnicities within the Greater East Asian Co-Prosperity Sphere (Oka 1943: 119). This lecture was regarded as a manifesto that actively placed the Minken as a support institution of the military government (Scheid 2016: 74).

Oka began by criticising the distinction between oral ethnicities (schriftlose Völker) and those with written traditions (schrifthistorische Völker), proposing that both should be studied in the same way. He also criticised European ethnology for its focus on "exotic ethnicities" (ekizochikku minzoku エキゾチック民族). Secondly, he proposed that ethnology should no longer limit its research to culture but also deal with the objective structure of all communities. Thirdly, he complained that ethnological research was too theoretical and he called for ethnologists to go out into the field to gather ethnographic descriptions so that their answers to questions such as "What is an ethnicity/a people (minzoku)? What is a tribe (shuzoku 種族)?" would be based on empirical evidence. Fourthly, while recognising the importance of the traditional historical aspect of ethnology, he emphasised the equal value of studying the contemporary realities of ethnicities (Oka 1943: 119-121). He concluded his lecture with the following plea:

Ethnology has to become the basis for ethnic policy [minzoku seisaku 民族政策] by clarifying the current actual structure of the ethnicities. Moreover, ethnologists should explore the ethnic 
awareness, the ethnic will, the personality, the tendencies and biases of the ethnic behaviour within the ethnic sentiment that is contained within this ethnic structure. [...] Japanese ethnology bears a heavy weight of responsibility; through collaboration we want to overcome this crisis and thereby develop a distinctive Japanese ethnology [Nihon dokuji no minzokugaku 日本独自 の民族学] that can meet the demands of our present situation" (Oka 1943: 122, paraphrased).

Many critical anthropologists today would certainly agree with most of the views expressed by Oka promoting a practical and impact-oriented ethnology. His lecture contains no language that supports imperialism and he does not seek to legitimise Japan's claim of superiority over other countries. On the contrary, he rejects any approach that imposes a hierarchy on ethnicities and differentiates between them based on criteria such as whether or not they possess a written tradition. In different political circumstances, the ideas put forward in this lecture would probably have been considered progressive. He appears to propose a methodology that is in some ways similar to the "personality and culture" studies prevalent at the US Office of War Information (OWI), which were carried out by anthropologists such as Clyde Kluckhohn and Ruth Benedict (and criticised by John Embree for its policy orientation). Shimizu concludes on Oka's initiatives to renew ethnology:

\begin{abstract}
Oka's initiative can be examined in two respects: what he refused and what he tried to create. In terms of the former, Oka was innovative in criticising and abandoning the type of anthropology that had specifically been created and maintained in the colonial situation. As for the latter point, if his proposal is interpreted as an approach to a particular people as they are living their contemporary life in a broader social context, Oka's proposal was also innovative in the sense that the necessity of such an approach was seriously recognised among post-structural anthropologists of Western metropolitan centres as late as in the 1980s (Shimizu 2003: 85).
\end{abstract}

On the other hand, Oka avoids any overt criticism of Japanese imperialism and its promotion of the Greater East Asia Co-Prosperity Sphere. Instead, he refers to "the present situation" as a crisis and stresses the importance of understanding minzoku with their various characteristics and sentiments in order to govern well. Clearly, he subscribes to the government's imperialistic agenda, and as Scheid (forthcoming) argues, his work at the Minken was also influenced by National Socialist ideas. Given that the lecture was delivered at a time when Oka was trying to persuade the government to finance and support the Ethnic Research Institute, his nod to government policy may have been inevitable, but Oka clearly took the lead in promoting and fundraising for the Minken.

Even though the Minken was financed by Shōwa Trading, its research agenda was not directly set by the military or by the government authorities. Instead, it followed Oka's appeal for a practical, empirical ethnology which could be used to establish ethnic policies for administering the minzoku under Japanese authority (Shimizu 2003: 85). As in other fields, many Japanese intellectuals did not need to be forced to comply with the government agenda; instead, they believed in the mission of 
imperialism and actively sought to work for government agencies, such as the South Manchurian Railway Company and various research institutes (cf. Shimizu 2003). Oka and his colleagues organised numerous field trips to Asian countries with the aim of "understanding the relations between Japan and surrounding Asian countries, some of them Japanese colonies at that time. This attempt was part of the efforts of anthropology to contribute to the construction of a modern Japanese national and cultural identity" (Ölschleger 2016: 119). Oka himself went to Manchuria and Inner Mongolia twice in 1944 for at least a month to conduct fieldwork (van Bremen 2003: 29). As anthropologist Jan van Bremen (2003: 30) points out, Japanese wartime anthropologists continued to focus on ethnography, whereas American anthropologists mainly turned their attention to evaluating government policy.

Members of the Minken held a series of public lectures in early 1945, which were published in Minzoku kenkyū 民族研究 in the same year (Shimizu 2003: 85). It is important to note, however, that the Minken had little time before the end of the war to produce data capable of influencing government policy and that their fundamental approach viewed those in the occupied territories as people with a comparable culture, structure, and characteristics as the Japanese rather than as an inferior and dehumanised enemy. The role of the Minken has been widely discussed but the original sources-which are held in the archive of the Museum of Ethnology in Ösaka (Minzoku Hakubutsukan or Minpaku 民族博物館、民博)—are still awaiting thorough study (Kreiner 2012: XXVI-XXVII).

With the end of the war, the Minken and all university departments of ethnology were closed, except for the one at the University of Tokyo (Shimizu 2003: 90). In autumn 1945, Oka returned to his home province in Nagano Prefecture and began rice farming due to the lack of work opportunities and also to avoid prosecution by the Allied Forces, although he continued to be in contact with his former colleagues (Kreiner 2016: 23; Oka 1981). The newly founded Democratic Scientists' Society (Minshūshugi kagaku 民衆主義科学 or Minka 民科) classed anthropology as a “warresponsible" discipline and their journal Minshūshugi kagaku (1946) contained a list of ninety "war-responsible" academics who should be purged from positions of responsibility. Oka's name appeared on this list because of his affiliation with the Minken but no specific accusations were levelled against him (Shimizu 2003: 92-93, 96).

In January 1947, Oka was summoned to the Allied General Headquarters in Tōkyō where he expected to be indicted for his collaboration with the wartime government. Instead, he was presented with a copy of his Vienna dissertation to translate and discuss with other Japanese academics in order to help develop a new ethnogenesis of the Japanese to replace the previous tennō mythology (Chun 2016). This summons was presumably on the initiative of his former classmate Kluckhohn, who by then had 
become co-director of the US Office of War Information ${ }^{23}$ (Nakao 2016: 132-136). Rather than translating the dissertation, Oka held a three-day symposium chaired by Ishida Ei'ichirō 石田英一郎 24 to discuss his arguments. The proceedings were published in the journal Minzokugaku kenky $\bar{u}$ in 1949 and later in book form (Kreiner 2016: 24-25). His hypothesis would dominate Japanese ethnology and cultural anthropology during the second half of the twentieth century (Kreiner 2012: XXVIIIXXIX).

According to Kreiner (2016: 25), however, by this time Oka was no longer excited about his earlier work and was more interested in present-oriented sociological and anthropological methods. In the early 1950s, he began to teach anthropology at several universities, becoming professor of Social Anthropology at Tokyo Metropolitan University (1953) and Meiji University (1960). Formally or informally, Oka helped to elevate a new generation of anthropologists and sociologists in post-war Japan (Oka Masao kyōju 1963; Kurainā 2013). The list of contributors to the Festschrift for Oka reads like a Who's Who of the world of Japanese anthropology and sociology. One of these, Nakane Chie, wrote in her eulogy: "In pre-war and post-war Japan, Professor Oka made very important contributions to the history of ethnology [minzokugaku], both as an organiser and a teacher" (Nakane 1963:331). Oka's international contribution in many Asian and European countries was recognised by his appointment as the first Asian president of the International Union of Anthropological and Ethnological Sciences from 1964-68 (IUEAS; Kreiner 2016: 29-30; Vidyarthy 1983).

\section{Oka's Ideological Stance and Legacy}

Given the political prominence of some of his teachers and colleagues as well as his own role in the furthering of ethnology during the time of Japanese imperialism and World War II, the question of Oka's political views and affiliations has been a major issue in the ongoing debate on his scholarship. On the first page of his (selected) collected works, Ijin sono ta (Strangers and Others; 1979), Oka assembled four photographs of the people to whom he felt most indebted: Schmidt, Heine-Geldern,

\footnotetext{
${ }^{23}$ By 1944, about ninety per cent of professional anthropologists in the US were affiliated with this office, including Ruth Benedict, who published the results of her wartime study of Japan in The Chrysanthemum and the Sword in 1946.

${ }^{24}$ Ishida Ei'ichirō (1903-1968) was a folklorist and interested in Marxism from an early age. Under the Peace Preservation Law (1925), he was sentenced to jail in 1926 and again from 1927 to 1934. After his release from jail (where he started to read ethnological literature), he attended lectures with Yanagita Kunio, where he was introduced to Oka who had just returned to Japan. Because Ishidaas opposed to Yanagita—did not make tenkō 転向 (i.e. renounce his left-leaning beliefs), he was not able to find a job. Oka managed to secure him a scholarship to study at the University of Vienna (Nakao 2005: 25-26).
} 
Shibusawa and Yanagita. Based on this and personal discussions with Oka, Kreiner (2012: XVI; 2017: 33) argues that Schmidt and Heine-Geldern were his most important influences in Vienna. There is no doubt that his closest relationship on a personal level was with Schmidt, who had "introduced him to the perspective of ethnohistory” (rekishi-minzokugaku no tachiba ni michibiite kureta 歴史民族学の立場に 導いてくれた; Oka 1979: dedication). They spent much time together and from spring 1930 until September 1932, when he began work on his Ph.D. dissertation, Oka lived close to the Monastery of St. Gabriel where Schmidt was based (Kreiner 2016: 12; Kreiner 2013), ${ }^{25}$ despite the inconvenience of an hour-long commute to lectures. Oka also visited Schmidt during his first visit to Europe in 1951, when they discussed the establishment of the Anthropos Institute at Nanzan University (Oka 1981: 673). As Scheid (2016) points out, Oka's theories are closer to those of Schmidt than of HeineGeldern, and in his dissertation he quotes from only one article by Heine-Geldern, although there is ample evidence that Oka and Heine-Geldern often met and exchanged ideas (Marschall 2016: 96-97). This reluctance to quote Heine-Geldern in his $\mathrm{Ph}$.D. is probably due to the fact that Schmidt required strict adherence to his theories from his students and refused to tolerate dissenting voices.

More generally, Schmidt's theories were highly controversial, but-according to Zimon - their special importance for ethnology was "not so much based on the results of his research as on the stimuli [they] gave to ethnologists" (Zimon 1986: 256). This statement also holds true for Oka. During his graduate student years, Oka appears to have been inspired by the basic ethnohistorical approach to exploring cultural similarities between ideas and objects in different parts of the world in order to arrive at a historical reconstruction of cultural strata for a given area in which there were no written sources and no means of deciding what was older and more recent (Marschall 2016: 86). According to Kreiner's (2013) analysis, Oka seems to have been most impressed by Heine-Geldern's methodology in this context. In Linhart's (2016: 77) view, Schmidt's important influence on Oka was his emphasis on the use of ethnology for practical purposes, which he later realised in his work at the Minken from 1943 to 1945, although at that time he was becoming more interested in studying contemporary practices and social structures.

In his role developing ethnic policies to help with the administration of people in the occupied territories, it can be argued that Oka was at the forefront of those who used ethnology and anthropology as a tool for the imperialistic government. There is, however, no indication of Oka actively contributing to oppressive policies or involvement in activities that could be construed as war crimes.

\footnotetext{
${ }^{25}$ Until then Oka lived in Porzellangasse in the ninth district of Vienna, which was around the corner from Sigmund Freud's apartment and within walking distance of the University (two or three tram stops to the University's main building and three more stops to the Hofburg where the Ethnology department was located).
} 
Overall, Oka seems to have been happy to cherry-pick aspects of a person's research which appealed to him rather than critically engaging those with whom he disagreed, even when the latter potentially discredited the research as a whole. For instance, in Völker und Kulturen he "just ignored the very rude anticommunist sentences by Koppers in the chapter on human economy" despite his own leaning towards Marxist theories when he first read the book (Marschall 2016: 87; cf. Oka 1981: 668). Although Oka — along with many other Japanese ethnologists — did not share the racial ideologies of the National Socialists and introduced minzokugaku to replace the racially charged term jinshugaku for ethnology/anthropology, he appears to have chosen to ignore Schmidt's anti-Semitism rather than attempting to distance himself from it. Like Schmidt, he had an ethnic (völkisch) rather than racial approach to anthropology and there are no records of him ever mentioning the subject of anti-Semitism (Scheid 2016: 65; Scheid forthcoming). Schmidt's concept of a primordial monotheism must also have appeared somewhat absurd to Oka, who although not overtly religious had described himself as a Shintoist in his matriculation documents and had grown up in a culture which recognises innumerable kami 神 (gods, spirits) (Kreiner 2016: 14). ${ }^{26}$ As said, he discussed religion at length, but not primordial monotheism.

Such detached ambivalence may create a somewhat opportunistic impression of Oka, but it is obvious that he wanted to avoid upsetting a teacher with whom he was personally very close (cf. Kreiner 2013). After Schmidt's death in 1954, HeineGeldern, who had returned to Vienna, and other colleagues officially "retracted" the Kulturkreistheorie and Schmidt became persona non grata within the field of social and cultural studies in Vienna. From this point onwards, it was perhaps more opportune for Oka, who had kept in contact with both Schmidt and Heine-Geldern, to emphasise Heine-Geldern's influence on his work (Scheid 2016: 63-64; cf. Zimoń 1986: 252).

While Oka had not shied away from conflict with Yanagita during his student days, he avoided openly contradicting the authorities on which he depended in later lifebe it Schmidt or the Japanese political establishment during the war. It is true that his $\mathrm{Ph} . \mathrm{D}$. dissertation contradicted the tenno-ideology, but very few people were aware of the ideas it contained as it was written in German and limited to three copies which were in libraries in Vienna. On the other hand, his criticism of European ethnologists who studied only oral ethnicities included Schmidt, but this work was only published in Japanese.

Oka appears to have chosen his teachers and friends based on personality and shared interests rather than ideological criteria. His best-loved teachers were a Catholic anti-Semite and an aristocrat of Jewish heritage; he helped his friend Ishida Ei'ichirō escape the kenpeitai 憲兵隊 (the military police) in Japan by inviting him to study in Vienna from 1937-1939 (Kreiner 2017: 38). Moreover, Oka helped him to

\footnotetext{
${ }^{26}$ Schmidt did not express any specific views on Shintoism (Linhart 2016: 71-22).
} 
get a job at the Seihoku Kenkyūjo 西北研究所 (Northwestern Research Institute) in Inner Mongolia, which was affiliated with the Minken (Yamashita, Eades and Shimizu 2018: 10). At the same time, one of his best friends was the National Socialist, Slawik, and Oka's work at the Minken was influenced by Nazi scientific policy.

These apparent contradictions make it impossible to assign Oka to a neat ideological box, but this does not mean that he was politically ignorant, socially naïve or lacking in any kind of convictions. ${ }^{27}$ Wide-ranging personal networks were central to the pursuit of his agenda both for his research and for fundraising, and as a "charismatic personality and skilled conversationalist, he was able to make connections with scholars, military authorities, and government" (Nakao 2005: 27). In other words, he convinced them to support his agenda by supporting theirs.

Nakane Chie provides an appraisal of Oka's character in her contribution to his Festschrift:

\begin{abstract}
Among his qualities are his broadmindedness, excellent decision-making capacities, his human warmth and perseverance. ... Those who observe Professor Oka from afar might have the impression that he is arrogant, but if you get closer, unless you have very strong prejudices, you are usually struck by his magnanimous personality and his charming wit. In fact, Professor Oka is an excellent speaker who can captivate his audience, although he is not necessarily such a good listener. One might well say that his appeal stems from his personality, but it is probably also due to the broad perspectives he gained through living in Europe for many years in his younger days. Professor Oka seems to be a product of the Japanese culture of the bushido ... and the glamorous pre-war culture of Europe. He appears equally at home taking a stroll along the Champs Elysees with a fair-haired woman as talking to an old granny at the fireside in the Japanese countryside (Nakane 1963: 331-334).
\end{abstract}

Not unlike a feudalistic patriarch, he seems to have been a somewhat overweening person who did not allow dissent, but at the same time he could be charming and caring towards others. Oka argued that his research agenda was politically useful and in this respect, he clearly placed his work within the "total war-mobilisation effort." Nevertheless, his goal does not appear to have been the development of the Co-Prosperity Sphere, but rather to understand the local people in occupied areas and administrate them successfully. As Shimizu notes, Oka and other Japanese anthropologists do "not seem to have made any substantial contributions in advocating the national and Asianist ideology" (Shimizu 2003: 64). Oka appears to have pursued his academic interests regardless of the political circumstances and made use of the opportunities presented to him to further his own academic interests, accepting - and even making a selling point of - the usefulness of his studies for the colonial and military efforts of

\footnotetext{
${ }^{27}$ Such a seemingly contradictory stance was not unique. Consider his friend and colleague To Yuho: he would perhaps have seen himself as a communist and later joined communist North Korea but chose to become a student of Menghin (who was responsible for the worst prosecution of Jewish and communist academics in Austria) and contributed to the Japanese translation of his supervisor's work.
} 
his country. As far as we know, Oka was not actively involved in politics and given that the Minken was short-lived, the influence of any of its findings on politics was marginal. The young discipline of ethnology was a minor participant in the mobilisation of science for political and military purposes (Shimizu 2003: 62), and Oka and his colleagues appear to have viewed the situation as an opportunity to push for greater recognition of their subject rather than to contribute to the war effort. Like many young people, Oka had read Marxist literature, but long lost interest. Because of the compatibility of his ideas with national politics, Oka was not required to perform tenkō 転向 (literally change direction), i.e. renounce his ideological commitment under pressure, as many intellectuals did at the time (cf. Shimizu 2003: 55-56). Oka may be described as an opportunist who, rather than criticising the wartime regime, adopted a pragmatic stance in order to persuade the authorities to support his research agenda. But it was also his conviction that his proposed form of ethnology could be used as a tool for successfully governing multi-ethnic territories.

\section{Oka's legacy for Japanese Studies in Vienna}

After the war, the Mitsui library at the University of Vienna - which had been evacuated to the countryside by Murata, Slawik, and others and thereby saved from bombing - was integrated into the Department of Ethnology library. Oka remained in Japan and Slawik was dismissed from the University in 1945 due to his Nazi background (Kreiner 1997: 4). The first post-war Minister of Education, the communist Ernst Fischer (April 27 to December 19, 1945), tried hard to encourage Jewish and progressive academics to return to Austria from exile but his efforts were largely unsuccessful. As a result, many former Nazis who recanted their earlier views and were not convicted of war crimes were eventually readmitted (Taschwer 2015b: 237-272). Koppers, the new head of the Department of Ethnology, recognised the part that Slawik had played in safeguarding the Mitsui library and employed him from 1948 as a research assistant and later as an Assistent (assistant professor) with responsibility for the Japan collection and for teaching classes on Japan. In 1964, Slawik was appointed Außerordentlicher Professor (associate professor) and in 1965 became the first head of the newly founded Japanese Studies department, a position he continued to hold until his retirement in 1971 (Kreiner 1997: 4). Kreiner, who had been Slawik's first student under the umbrella of the Department of Ethnology, succeeded to the chair after Slawik's retirement. He studied Ainu and Okinawan cultures and earned his habilitation from the University of Bonn. Kreiner was appointed professor at the University of Bonn in 1977, but he continued to teach in Vienna until 1978 when he was succeeded by Sepp Linhart, another of Slawik's students and Kreiner's Assistent. Linhart was the only full professor of Japanese Studies in Austria until taking up an 
emeritus position in 2012. Oka stayed in contact with the department until shortly before his death in 1982 .

Under the revised University Organisation Act of 1975, University structures became more democratic and Linhart's Assistenten (assistant and associate professors) became largely independent researchers and teachers. Linhart's research focused on contemporary social issues (before moving on to Edo-period popular culture in the 1990s), and this was also true for most of his colleagues. When I arrived at the University in the mid-1980s, we learned little about ethnogenesis but instead studied social history, including labour conditions, leisure, the lives of burakumin 部落民 and of women. We also learned about Japanese imperialism and comfort women. Thus, Oka's conviction in later life of the need to study actual people, their characteristics, motivations, and sentiments and to avoid approaching Japan as an "exotic" culture appears to have left more of a lasting legacy than his research agenda while a student in Vienna. Until recently, interest in Oka was limited and I cannot recall ever reading his work in any of my classes. Nevertheless, Oka's influence on the "Vienna School of Japanese Studies," which prides itself on consolidating the philological roots, the anthropological/ethnographic tradition, and the reflexive social sciences from various strands of Japanese Studies under one umbrella, ${ }^{28}$ deserves wider recognition.

Oka's written oeuvre is modest and his former students have all retired or passed away. He has been forgotten by all but a small group of researchers and many questions about his life and legacy remain unanswered. Nevertheless, Oka's intellectual influence has penetrated post-war academic life and many academics in positions of authority have consciously or unconsciously followed his lead. I hope that this review of recent scholarship on Oka Masao and some of the intellectual connections between Europe and Japan will help a new generation to discover a researcher who "casts a spell on people" (Bernhard Scheid, personal communication, September 2017) when they begin to learn about his life and work.

\section{REFERENCES}

Benedict, Ruth. 1946. The Chrysanthemum and the Sword: Patterns of Japanese Culture. Boston: Houghton Mifflin.

Christy, Alan. 2012. A Discipline on Foot: Inventing Japanese Native Ethnography. Plymouth: Rowan \& Littlefield Publishers.

Chun, Kyung-Soo. 2016. "Why did GHQ Bring Oka's Dissertation from Vienna to Tokyo?" In Ishikawa et al., pp. 129-151.

Coleridge, William. 2019. “Tetsudō: Japan's Railway Pan-Asianism 1905-1945.” B.A. thesis, University of Cambridge, United Kingdom.

\footnotetext{
${ }^{28}$ See: https://japanologie.univie.ac.at/geschichte-und-ausrichtung/ (accessed July 3, 2019).
} 
Erker, Linda, Andreas Huber, and Klaus Taschwer. 2017. "Von der 'Pflegestätte nationalsozialistischer Opposition' zur 'äußerst bedrohlichen Nebenregierung.' Der Deutsche Klub vor und nach dem 'Anschluss' 1938." Zeitgeschichte, 44 (2), pp. 78-134.

Fukui, Katsuyoshi. 2004. “Oka Masao.” In Vered Amit, ed., Biographical Dictionary of Social and Cultural Anthropology. London: Routledge, p. 387.

Gingrich, Andre and Peter Rohrbacher, eds. Forthcoming. Völkerkunde aus Wien zur NS-Zeit. Vienna: Verlag der Österreichischen Akademie der Wissenschaften.

Haruna, Mikio 春名幹男. 2000. Himitsu no fairu: CIA no tainichi kōsaku 1 秘密のファイル: CIA の対日工作・上 [Secret Files: CIA Activities towards Japan 1]. Tōkyō 東京: Kyōdō Tsūshinsha 共同通信社.

Hohenwart-Gerlachstein, Anna. 1983. "In Memoriam Masao Oka." Bulletin of the International Committee on Urgent Anthropological and Ethnological Research, 25, pp. 11-16.

Huber, Andreas. 2017. "Katholisch-deutschnationale Eliten: Cartellverband, Deutscher Klub und ihre Mitglieder in der Hochschullehrerschaft der Universität Wien 1932-1950." In Frank-Michael Kuhlemann and Michael Schäfer, eds., Kreise, Bünde, Intellektuellennetzwerke: Formen bürgerlicher Vergesellschaftung und politischer Kommunikation 1890-1960. Bielefeld: Transcript, pp. 189-220.

Ishikawa, Hideshi, Josef Kreiner, Sasaki Ken'ichi, and Yoshimura Takehiko, eds. 2016. Proceedings of the International Symposium on Origins of Oka Masao's Anthropological Scholarship, Meiji University, November 27, 2015. Bonn: Bier'sche Verlagsanstalt.

Kluckhohn, Clyde. 1936. "Some Reflections on the Method and Theory of the Kulturkreislehre." American Anthropologist, 38 (2), pp. 157-196.

Köck, Stefan. 2017 [published 2019]. “Antisemitismus und Denunziantentum als einzige Option? Ramming, Gundert und die Frage nach Handlungsspielräumen für Japanologen in der nationalsozialistischen Diktatur.” Bochum Yearbook of East Asian Studies (BJOAF), 40, pp. 133-153.

Kodansha Encyclopedia of Japan. 1999. “Marebito [客人 ].” Japan Knowledge Library; online: https://japanknowledge.com/library/en/ (accessed: September 2, 2019).

Kondō, Masanori 近藤正憲. 1998. “Mitsui Takaharu no tai Tōō bunka jigyō: Hangarī no kēsu o chūshin ni 三井高陽の対東欧文化事業 : ハンガリーのケースを中心に [Mitsui Takaharu's Cultural Engagement in Eastern Europe: The Case of Hungary]." Chiba daigaku shakai bunka kagaku kenky $\bar{u}$ 千葉大学大学院社会文化科学研究科 [Social Science and Humanities, Chiba University], 2, pp. 33-63.

Kovács, Isabella. 1987. "Historische Dokumentation der ungarisch-japanischen Kulturbeziehungen von ihren Anfängen bis zur Gegenwart.” Ph.D. thesis, University of Vienna, Austria.

Kreiner, Josef. 1998. “Alexander Slawik zum Gedenken (27.12.1900-19.4.1997).” Nachrichten der Ostasiatischen Gesellschaft NOAG, 161-162, pp. 1-5.

Kreiner, Josef. 2012. “Oka Masao (1898-1982) und sein Werk Kulturschichten in Alt-Japan.” In Josef Kreiner, ed., Oka Masao: Kulturschichten in Alt-Japan. Bonn: Bier'sche Verlagsanstalt, IX-XXXVI.

Kreiner, Josef. 2013. "Die Gründung des Instituts für Japankunde an der Universität Wien.” In Ingrid Getreuer-Kargl and Sepp Linhart, eds., Die Republik Österreich und Japan während der Zwischenkriegszeit 1918-1938 (1945). Wien: Abteilung für Japanologie des Instituts für Ostasienwissenschaften der Universität Wien, pp. 217-253.

Kreiner, Josef. 2016. "Oka Masao: The Man and His Footprints in Japanese Ethnology and Viennese Japanology.” In Ishikawa et al., pp. 3-39.

Kreiner, Josef. 2017. "Brief Remarks on Paradigm Shifts in Japanese Anthropology during the 20th Century." Global Perspectives on Japan, 1, pp. 23-65. 
Linhart, Sepp. 2016. “Oka Masao Meets Wilhelm Schmidt and Wilhelm Koppers: From the Country of Eight Million Gods to a Country of One Almighty God Belief." In Ishikawa et al., pp. 153-172.

Marschall, Wolfgang. 2016. "The Viennese Roots of Oka Masao.” In Ishikawa et al., pp. 79-98.

Menghin, Oswald. 1940. Weltgeschichte der Steinzeit. 2nd edition. Wien: A. Schroll \& Co.

Meshcheryakov, Aleksander N. 2018. "Ethnologist Yanagita Kunio: Long Road to Recognition." Russian Japanology Review, 1, pp. 72-90.

Minerva ミネルヴァ. 1937. “Gakkai ōrai: APE no tanjō 学会往来:APE の誕生 [Research Associations, News].” Minerva, February, p. 36.

Nakamura, Daisuke. 2016. "Oka Masao's Theories on the Japanese Ethnogenesis with Special Reference to Migrations from the South.” In Ishikawa et al., pp. 211-232.

Nakane, Chie 中根千枝. 1963. “Oka Masao sensei no purofaiiru 岡正雄先生のプロファイル [Professor Oka Masao's Profile].” In Oka Masao kyōju kanreki kinen bunshū henshū iinkai 岡正雄 教授還暦記念文集編集委員会, ed., Minzokugaku nōto: Oka Masao kyōju kanreki kinen bun$s h \bar{u}$ 民族ノート: 岡正雄教授還暦記念文集 [Notes on Ethnology: Festschrift for Professor Oka Masao]. Tōkyō 東京: Heibonsha 平凡社, pp. 331-350.

Nakao, Katsumi. 2005. "The Imperial Past of the Anthropology of Japan.” In Jennifer Robertson, ed., A Companion to the Anthropology of Japan. Oxford: Blackwell Publishing, pp. 19-35.

Nakao, Katsumi. 2016. "Clyde Kuckhohn: Political Position and his Tactics for Applied Anthropology in the US.” In Ishikawa et al., pp. 61-98.

Oka, Masao 岡正雄. 1941. “Ōshū ni okeru minzoku kenkyū 欧州に於ける民族研究 [Ethnic Research in Europe].” Kaizō 改造 [Renewal], 8, pp. 64-66.

Oka, Masao 岡正雄. 1943. “Gendai minzokugaku no shomondai 現代民族学の諸問題 [Various issues of Contemporary Ethnology].” Minzokugaku kenkyu 民族学研究 [Ethnology Studies], 1 (1), pp. 119-122.

Oka Masao kyōju [kanreki kinen bunshū henshū iinkai] 岡正雄教授還暦記念文集編集委員会, ed. 1963. Minzokugaku nōto: Oka Masao kyōju kanreki kinen bunshū 民族ノート: 岡正雄教授 還暦記念文集 [Notes on Ethnology: Festschrift for Professor Oka Masao]. Tōkyō 東京: Heibonsha 平凡社.

Oka, Masao 岡正雄. 1979. Ijin sono ta: Nihon minzoku = bunka no genryū to Nihon kokka no keisei 偉人その他。日本民族＝文化の源流と日本国家の形成. [Strangers and Others: The Origins of Japanese Ethnos $=$ Culture and the Formation of the Japanese State]. Tōkyō 東京: Gensōsha 言叢社.

Oka, Masao 岡正雄. 1981. “Oka Masao-shi danwa 岡正雄氏談話 [Interview with Oka].” In Shibusawa Keizō denki hensan kankōkai 渋沢敬三伝記編纂刊行会, ed., Nihon ginkō denshutsugo 渋沢敬三伝記編纂刊行会編:日本銀行転出後 [After Leaving the Bank of Japan]. Tōkyō 東京: Shibusawa Keizō denki hensan kankōkai 渋沢敬三伝記編纂刊行会, pp. 664-689.

Oka, Masao. 2012. Kulturschichten in Alt-Japan, ed. and introduced by Josef Kreiner. Bonn: Bier'sche Verlagsanstalt.

Ölschleger, Hans Dieter. 2016. “Oka Masao and Alexander Slawik: Mutual Influences between Japanese and German-speaking Ethnologies.” In Ishikawa et al., pp. 173-192.

Nakazawa Shin'ichi 中沢新一. 2008. Orikuchi Shinobu: Kodai kara kita miraijin 折口信夫: 古代 から来た未来人 [Orikuchi Shinobu: The Ancient People Who Came from the Future]. Tōkyō 東京: Chikuma Purimā Shinsho ちくまプリマー新書.

Price, David. 2002a. "Past Wars, Present Dangers, Future Anthropologies.” Anthropology Today, 18 (1), pp. 22-23. 
Price, David. 2002b. "Lessons from Second World War Anthropology: Peripheral, Persuasive and Ignored Contributions." Anthropology Today, 18 (3), pp. 14-20.

Rivinius, Karl Josef. 2013. "Wissenschaft im Dienste der Evangelisierung: Der Beitrag der Katholischen Fu-Jen-Universität in Peking.” In Claus Arnold and Johannes Wischmeyer, eds., Transnationale Dimensionen wissenschaftlicher Theologie. Göttingen: Vandenhoeck \& Ruprecht, pp. 195-236.

Scheid, Bernhard. 2016. “Oka Masao und das schwierige Erbe der Wiener Kulturkreislehre.” In Ralph Lützeler and Wolfram Manzenreiter, eds., Aso: Vergangenheit, Gegenwart und Zukunft eines Wiener Forschungsprojektes zum ländlichen Japan. Vienna: Abteilung für Japanologie des Instituts für Ostasienwissenschaften, University of Vienna (= Beiträge zur Japanologie 45), pp. 61-87.

Scheid, Bernhard. Forthcoming. "Der Ethnologe als Geburtshelfer nationaler Identität: Oka Masao und seine Netzwerke, 1935-1945." In Andre Gingrich and Peter Rohrbacher, eds., Völkerkunde aus Wien zur NS-Zeit. Vienna: Verlag der Österreichischen Akademie der Wissenschaften.

Schirmer, Andreas. 2016. "Korean Students in Europe Related to Oka Masao: Direct and Indirect Connections.” In Ishikawa et al., pp. 99-128.

Schmidt, Wilhelm. 1935a. Neue Wege zur Erforschung der ethnologischen Stellung Japans [New Ways of Researching the Japanese Ethnological Position]. Tōkyō 東京: Kokusai Bunka Shinkōkai 国際文化振興会.

Schmidt, Wilhelm. 1935b. "The Oldest Culture-Circles in Asia.” Monumenta Serica, 1 (1), pp. 116.

Shimizu, Akitoshi. 2003. "Anthropology and the Wartime Situation of the 1930s and 1940s: Masao Oka, Yoshitarō Hirano, Eiichirō Ishida and their Negotiations with the Situation.” In Shimizu Akitoshi and Jan van Bremen, eds., Wartime Japanese Anthropology in Asia and the Pacific (= Senri Ethnological Studies no. 65). Osaka: National Museum of Ethnology, pp. 49108.

Shimizu, Akitoshi 清水昭俊. 2013. “Ijin, genzaigaku-teki minzokugaku, soshite shuzokushi-teki keisei: Oka Masao to Nihon-minzokugaku no tenkai 異人、現在学的民族学、そして種族史 的形成: 岡正雄と日本民族学展開 [Others, Present-Oriented Ethnology, and the Historic Formation of Races].” In Josef Kreiner $コ$ ゼフ・クライナー, ed., Nihon minzokugaku no senzen to sengo: Oka Masao to Nihon minzokugaku no kusawake 日本民族学の戦前と戦後: 岡正雄と 日本民族学の草分け [Ethnology in Prewar and Postwar Japan: Oka Masao and the Pioneers of Japanese Ethnology]. Tōkyō 東京: Tōkyōdō Shuppan 東京堂出版, pp. 67-142.

Shimizu, Akitoshi. 2018. “Oka, Masao (1898-1982).” In Hilary Callan, ed., The International Encyclopedia of Anthropology. New York: John Wiley \& Sons. DOI: 10.1002/9781118924396.wbiea1431.

Slawik, Alexander. 1936. "Kultische Geheimbünde der Japaner und Germanen (eine vergleichende Studie).” Wiener Beiträge zur Kulturgeschichte und Linguistik, 4, pp. 675-763.

Taschwer, Klaus. 2015a. "Nachrichten von der antisemitischen Kampfzone. Die Universität Wien im Spiegel und unter dem Einfluss der Tageszeitungen, 1920-1933.” In Margarete Grandner and Thomas König, eds: Reichweiten und Außensichten. Die Universität Wien als Schnittstelle wissenschaftlicher Entwicklungen und gesellschaftlicher Umbrüche. Göttingen: Vienna University Press, pp. 99-126.

Taschwer, Klaus. 2015b. Hochburg des Antisemitismus. Der Niedergang der Universität Wien im 20. Jahrhundert. Wien: Czernin Verlag.

Umemura, Yuko. 2017. Japánok és magyarok egymásról [What Japan and Hungary Think of Each Other]. Budapest: Akadémia Kiadó. 
van Bremen, Jan. 2003. "Wartime Anthropology: A Global Perspective.” In Shimizu Akitoshi and Jan van Bremen, eds., Wartime Japanese Anthropology in Asia and the Pacific (= Senri Ethnological Studies no. 65). Osaka: National Museum of Ethnology, pp. 13-48.

Vidyarthy, L.P. 1983. “Obituary: Masao Oka.” Current Anthropology, 24 (2), p. 268.

Yamashita, Shinji, J.S. Eades, and Shimizu Akitoshi. 2018. "Anthropology in Japan.” In Hilary Callan, ed., The International Encyclopedia of Anthropology. New York: John Wiley \& Sons. DOI: 10.1002/9781118924396.wbiea1754.

Yanagida (= Yanagita), Kunio. 1944. "Die japanische Volkskunde: Ihre Vorgeschichte, Entwicklung und gegenwärtige Lage / The Science of Japanese Folklore: Its Origin, Development and Present Condition / 日本民俗学.” Folklore Studies, 3 (2), pp. 1-76.

Zimoń, Henryk. 1986. "Wilhelm Schmidt's Theory of Primitive Monotheism and its Critique within the Vienna School of Ethnology." Anthropos, 81 (1), pp. 243-260.

\section{GLOSSARY}

\begin{tabular}{|c|c|c|}
\hline APE-kai & APE 会 & $\begin{array}{l}\text { archaeology, prehistory, ethno- } \\
\text { logy association }\end{array}$ \\
\hline bukanshitsu & 武官室 & military office \\
\hline bunka jinruigaku & 文化人類学 & cultural anthropology \\
\hline burakumin & 部落民 & $\begin{array}{l}\text { descendants of a discriminated } \\
\text { class }\end{array}$ \\
\hline danwa & 談話 & conversation, interview \\
\hline danwa-kai & 談話会 & discussion circle \\
\hline dengaku & 田楽 & $\begin{array}{l}\text { musical accompaniment or } \\
\text { dances for rice planting }\end{array}$ \\
\hline desupere & デスペレ & desperate \\
\hline Egami Namio & 江上波夫 ～～～～～～～ & 1906-2002 \\
\hline ekizochikku minzoku & エキゾチック民族 & exotic ethnicities \\
\hline Fu Jen University & 輔仁大學 & \\
\hline Furuno Kiyoto & 古野 清人 & 1899-1979 \\
\hline Han Hŭng-su & 韓興洙 & $\begin{array}{l}\text { aka Han Hung-Soo or Han } \\
\text { Hung-Su; 1909-? }\end{array}$ \\
\hline hidane & 火種 & spark \\
\hline Ijin sono ta & 異人その他 & Strangers and Others \\
\hline Ishida Ei'ichirō & 石田英一郎 & $1903-1968$ \\
\hline jinbun kenkyūkai & 人文研究会 & Humanities Research Group \\
\hline jinshugaku & 人種学 & $\begin{array}{l}\text { "race studies," "human species } \\
\text { studies" (anthropology) }\end{array}$ \\
\hline jōmu riji & 常務理事 & managing director \\
\hline Kaizō & 改造 & $\begin{array}{l}\text { Journal titled "Kaizo" [Renewal } \\
\text { or literally Remodelling] }\end{array}$ \\
\hline kami & 神 & gods, spirits \\
\hline kenpeitai & 憲兵隊 & the military police \\
\hline Manyōshū & 万葉集 & $\begin{array}{l}\text { oldest Japanese poetry collec- } \\
\text { tion }\end{array}$ \\
\hline Mao Zedong & 毛泽东 & $1893-1976$ \\
\hline
\end{tabular}


marebito

matsuri

Minka

Minshūshugi kagaku

Minzoku

Minzoku Hakubutsukan (Minpaku)

Minzoku kenkyū

Minzoku kenkyūjo (Minken)

minzoku seisaku

minzokugaku

minzokugaku

Minzokugaku kenkyūkai

Mitsui Takaharu

mokuyō-kai

Murata Toyofumi

Nanzan University

Nihon bunka jinrui gakkai

Nihon dokuji no minzokugaku

Nihon minzoku gakkai

Oka Masao

Oka Shigeo

Oka Shoin

Okamura Chiaki

Orikuchi Shinobu

Sajima Yoshinari

sarugaku

Sasaki Hikoichirō

Seihoku Kenkyūjo

sesse to

Shibusawa Ei'ichi

Shibusawa Keizō

Shiratori Kurakichi

shosei

shōsū minzoku

Shōwa Tsūshō

shuzoku

Suda Akiyoshi

Takahashi Buntarō

Takebe Tongo

tenkō

tennō
客人、賓

祭り

民科

民衆主義科学

民族

民族博物館（民博）

民族研究

民族研究所 (民研)

民族政策

民族学

民俗学

民族学研究会

三井高陽

木曜会

村田豊文

南山大学

日本文化人類学会

日本独自の民族学

日本民族学会

岡正雄

岡茂雄

岡書院

岡村千秋

折口信夫

佐島敬愛

猿楽

佐々木 彦一郎

西北研究所

せっせと

渋沢栄一

淽沢敬三

白鳥庫吉

書生

少数民族

昭和通商

種族

須田昭義

高橋文太郎

建部遯吾

転向

天皇 other-worldly beings

Shinto festival

abbreviation of Minshushugi

kagaku

Democratic Scientists' Society

Ethnos (journal)

Museum of Ethnology

academic journal

Ethnic Research Institute

ethnic policy

ethnology, Völkerkunde

folklore studies

Ethnological Society

1900-1983

Thursday meetings (Yanagita

Kunio)

The Japanese Society of Cultural Anthropology (JASCA) distinctive Japanese ethnology Ethnological Society of Japan 1898-1982

1894-1989

publishing company

1884-1941

1875-1962

1904-1990

ancient popular theatre enter-

tainment

1901-1936

Northwestern Research Institute

assiduously

1840-1931

1896-1963

1865-1942

small ethnicities

Shōwa Trading

tribe

1900-1990

1903-1948

1871-1945

political conversion

emperor 
To Yu-ho

Tōa Tabako

tokoyo

Tokoyo oyobi marebito

Torii Ryūzō

Tsuboi Shōgorō

Uìn tsūshin

Yahata Ichirō

Yanagita Kunio

zaibatsu

Zaidan hōjin Nihon Minzokugaku-kyōkai
都宥浩

東亜タバコ

常世

常世及びまれびと

鳥居龍蔵

坪井正五郎

ウィーン通信

八幡一郎

柳田國男

財閥

財団法人日本民族学協会 aka Do Cyong-Ho, 1905-?

East Asia Tobacco Company

the other world

The Other World and Marebito

1870-1953

1803-1913

Vienna Correspondence

1902-1987

1875-1962

industrial and financial business conglomerate

Japanese Ethnological Society

Foundation 